\title{
DESAIN MODUL PEMBELAJARAN GEOMETRI DENGAN PENDEKATAN CONTEKSTUAL TEACHING AND LEARNING UNTUK SISWA SEKOLAH DASAR
}

\author{
Dyah Tri Wahyuningtyas ${ }^{1}$ \\ Nury Yuniasih ${ }^{1}$ \\ Edy Bambang Irawan ${ }^{2}$ \\ Susiswo $^{2}$ \\ ${ }^{1}$ Universitas Kanjuruhan Malang, Jl. S. Supriadi no 48, Malang \\ ${ }^{2}$ Universitas Negeri Malang, Jl. Semarang no 5, Malang \\ email: dyahtriwahyu@unikama.ac.id
}

\begin{abstract}
The research aimed to develop module of geometry learning with CTL approach in grade 4 and 5 primary school. The geometry learning module consists of two-dimensional figure and three-dimensional shape material. The development model used is divided into three phases as initial investigation, prototype, and assessment. The research instruments used validation sheets and questionnaires. The results showed that the product has reached valid criteria with score 3,65 (high criterion). Based on the validation result, the learning module of geometry with CTL approach for grade 4 and 5 primary school is declared valid and can be applied.
\end{abstract}

Keyword: CTL, geometry, learning module, primary school.

\begin{abstract}
Abstrak: Penelitian bertujuan mengembangkan modul pembelajaran geometri dengan pendekatan CTL di kelas IV dan V SD. Modul pembelajaran geometri terdiri dari materi bangun datar dan bangun ruang. Model pengembangan yang digunakan terbagi menjadi tiga fase yaitu investigasi awal, prototipe, dan asesmen. Instrumen penelitian yang digunakan lembar validasi dan angket respon ahli dan praktisi. Hasil penelitian menunjukkan bahwa produk modul pembelajaran geometri dengan pendekatan CTL telah memenuhi kriteria valid dengan ketercapaian validasi modul 3,65 (kriteria tinggi). Berdasarkan hasil validasi tersebut, dapat disimpulkan bahwa modul pembelajaran geometri dengan pendekatan CTL untuk kelas IV dan V SD dinyatakan valid sehingga dapat diterapkan di SD.
\end{abstract}

Kata Kunci: CTL, geometri, modul pembelajaran, SD

Matematika perlu dibelajarkan kepada semua siswa mulai dari sekolah dasar untuk membekali mereka dengan kemampuan berfikir logis, analitis, sistematis, kritis, dan kreatif, serta kemampuan berkerjasama (BSNP, 2006). Hal ini sejalan dengan fungsi dan tujuan pendidikan nasional yang tertuang dalam Undang-Undang Nomor 20 Tahun 2003 Pasal 3 yang menetapkan bahwa pendidikan nasional berfungsi untuk mengembangkan kemampuan dan membentuk watak serta peradaban bangsa yang bermarta- bat dalam rangka mencerdaskan kehidupan bangsa, bertujuan untuk mengembangkan potensi siswa agar menjadi manusia yang beriman dan bertakwa kepada Tuhan yang Maha Esa, berakhlak mulia, sehat, berilmu, cakap, kreatif, mandiri, dan menjadi warga negara yang demokratis serta bertanggung jawab.

Teori pembelajaran konstruktivisme merupakan teori pembelajaran yang menyatakan bahwa siswa harus menemukan sendiri dan mentransformasikan informasi kompleks, mengecek informasi 
baru dengan aturan-aturan lama dan merevisinya apabila aturan-aturan itu tidak sesuai lagi (Trianto, 2010:74). Guru dapat memberikan kemudahan dengan memberikan siswa kesempatan untuk menemukan dan menerapkan ide-ide mereka sendiri, dan membelajarkan kepada siswa secara sadar menggunakan strategi mereka sendiri untuk belajar. Pembelajaran kontekstual merupakan salah satu unsur dari Contekstual Teaching and Learning (CTL) yang sesuai dengan teori konstruktivisme. Salah satu peranan penting CTL dalam pendidikan yaitu filosofi belajar yang menekankan bahwa belajar tidak hanya sekedar menghafal namun harus kontekstual bagi siswa.

Pada pembelajarannya, materi pokok matematika yang dipelajari di SD terdiri atas materi bilangan, aljabar, pengukuran, serta geometri (Depdiknas, 2006). Siswa sudah mengenal bentuk-bentuk geometri melalui benda-benda yang ada disekelilingnya seperti bola, meja, jam dinding, layang-layang, dan sebagainya. Namun, ditemukan indikasi bahwa pembelajaran geometri kurang mendapat perhatian oleh guru. Hal ini diperkuat oleh Kahfi (1997:31) yang menyatakan bahwa geometri merupakan bidang yang paling terabaikan dalam kurikulum matematika di SD. Hal ini dikarenakan siswa kesulitan dalam menghafal rumus-rumus tentang keliling, luas bangun datar, luas permukaan dan volume bangun ruang.

Melalui landasan filosofi konstruktivisme tersebut, CTL dipromosikan menjadi alternatif strategi belajar yang baru. Melalui strategi CTL, siswa diharapkan belajar melalui kegiatan mengalami dan bukan hanya menghafal (Nurhadi, 2009:10). Pengetahuan bukanlah seperangkat fakta-fakta, konsep, atau kaidah yang siap untuk diingat dan diambil. Manusia harus mengkonstruksi pengetahuan itu dan memberi makna melalui pengalaman nyata. Oleh karena itu, dalam CTL, strategi untuk membelajarkan siswa menghubungkan antara setiap konsep dengan kenyataan merupakan unsur yang diutamakan dibandingkan dengan penekanan terhadap seberapa banyak pengetahuan yang harus diingat oleh siswa.

Hasil analisis terhadap buku siswa dari pemerintah menunjukkan bahwa buku siswa dirasa masih kurang dalam membangun konsep matematika serta dalam mengembangkan kreatifitas siswa secara mandiri. Hal ini diperkuat oleh Yuniasih (2013) yang menyatakan bahwa pelaksanaan tematik terpadu di lapangan masih dirasa kurang dalam segi isi atau materi. Materi pembelajaran yang ada pada buku ajar perlu dikembangkan agar dapat meningkatkan kualitas pembelajaran. Guru perlu mengembangkan bahan ajar yang menarik dan bervariasi dengan berbasis IT untuk mengurangi kejenuhan dan anggapan bahwa matematika adalah pelajaran yang sulit. Dengan mengembangkan bahan ajar, selain dapat meningkatkan kemampuan guru juga dapat meningkatkan hasil belajar dan keterampilan siswa. Bahan ajar yang dikembangkan guru harus sesuai dengan lingkungan dan kemampuan siswa serta dapat meningkatkan kemandirian dan keterampilan siswa. Untuk memaksimalkan kemandirian siswa tersebut diperlukan suatu bahan belajar mandiri yang terstruktur, salah satunya dicapai melalui pemberian modul pembelajaran yang berkualitas.

Berdasarkan hal tersebut maka tujuan penelitian pengembangan ini adalah untuk merancang dan mengembangkan modul pembelajaran geometri yang valid dengan mengembangkan delapan unsur pada pendekatan CTL yang dimodifikasi dan disesuaikan dengan pelaksanaan kurikulum 2013. Keutamaan pengembangan bahan ajar berupa modul yang dikembangkan dengan CTL ini merupakan upaya untuk meningkatkan kualitas pembelajaran untuk mendapatkan pembelajaran yang bermakna khususnya dalam pembelajaran geometri.

Modul pembelajaran matematika ini diharapkan dapat membantu guru dalam mengembangkan materi pembelajaran yang ada pada buku guru dan buku siswa serta dapat meningkatkan hasil belajar siswa dalam memahami materi geometri bangun datar dan bangun ruang serta dapat meningkatkan kemampuan kognitif melalui pemecahan masalah, meningkatkan kemandirian, serta dapat memotivasi siswa untuk belajar. Spesifikasi produk modul pembelajaran matematika yang dikembangkan ini merupakan modul mandiri untuk siswa pada materi geometri yang berisi aktivitas untuk meningkatkan pemahaman, berfikir kritis dan kreatif melalui pemecahan masalah, pengajuan pertanyaan, serta penyelesaian masalah open endeed yang dilengkapi dengan media untuk menamkan konsep geometri yaitu bangun datar dan bangun ruang.

\section{METODE}

Tujuan dari penelitian ini adalah mengembangkan modul pembelajaran geometri dengan pendeka$\tan$ CTL untuk siswa sekolah dasar yang valid, prak- 
tis dan efektif. Jenis penelitian ini termasuk dalam penelitian pengembangan pendidikan (educational design research). Pengembangan Modul pembelajaran pada penelitian ini mengikuti fase-fase pengembangan model yang dikemukakan oleh Plomp (2007). Fase-fase pengembangan tersebut dilakukan dalam tiga fase, yaitu: (1) fase investigasi awal (preliminary research), (2) fase prototipe (prototyping phase), dan (3) fase asesmen (assessment phase). Berikut ini secara berturut-turut diuraikan kegiatan yang dilakukan pada tiap-tiap fase pengembangan.

Pada fase investigasi awal, peneliti melakukan: (1) analisis awal dalam bentuk kajian terhadap bahan ajar yang beredar di lapangan, secara spesifik bagaimana karakteristik bahan ajar yang digunakan, mengkaji ketersediaan sumber-sumber belajar dan situasi pembelajaran dengan berbagai fasilitas yang ada termasuk buku penunjang, dan kondisi pembelajaran yang sedang berjalan. (2) analisis siswa melalui pengamatan terhadap bagaimana kemandirian siswa dalam belajar. (3) analisis materi terhadap kajian materi bilangan bulat yang ada pada bahan ajar yang beredar di lapangan. (4) analisis tugas terhadap kajian terhadap tugas-tugas yang ada pada bahan ajar yang beredar di lapangan. Setelah selesai melakukan analisis awal, analisis siswa, analisis materi, dan analisis tugas maka akan dilakukan (5) penyusunan indikator pembelajaran yang disesuaikan dingan kompetensi dasar dan kompetensi inti yang ada pada kurikulum 2013.

Berdasar hasil pengamatan, refleksi dan analisis hasil observasi awal, pada fase prototipe disusun rancangan penyelesaian masalah. Rancangan yang dibuat terdiri dari; (1) rancangan modul pembelajaran, (2) rancangan perangkat pembelajaran dan (3) rancangan instrumen penelitian. Ketiga rancangan ini disusun bersamaan. Selanjutnya, pada fase asesmen dilakukan validasi ahli pada modul, perangkat pembelajaran, dan instrumen. setelah validasi dilakukan ujicoba modul dan perangkat pembelajaran tersebut. Analisis data kevalidan produk diperoleh dari hasil pada angket validasi modul oleh seorang pakar pembelajaran, seorang pakar pendidikan matematika, serta seorang praktisi yaitu guru di sekolah dasar. Analisis ini dilakukan untuk menilai apakah modul dan instrumen penelitian yang disusun telah memenuhi kriteria kevalidan. Karena data kevalidan modul dan instrumen telah dikonversi ke data kuantitatif, maka data ini dianalisis dengan analisis deskriptif.

\section{HASIL}

Pengembangan modul yang dilakukan ini mengikuti tahapan pengembangan yang dikemukakan Plomp (2007), yaitu: (1) fase investigasi awal, (2) fase prototipe, dan (3) fase asesmen. Hasil pengembangan modul materi geometri dari kedua tahapan tersebut adalah sebagai berikut.

\section{Fase Investigasi Awal}

Pada fase investigasi awal, peneliti melakukan observasi awal pada sepuluh sekolah dasar berbeda di Kota Malang. Pengamatan secara cermat dilakukan terhadap hal-hal antara lain: (1) analisis awal; (2) analisi siswa; (3) analsisi materi. Pada tahap analisis awal kegiatan yang dilakukan bertujuan untuk mengetahui pelaksanaan pembelajaran tematik di lapangan serta ketersediaan sumber-sumber belajar dan situasi pembelajaran dengan berbagai fasilitas yang ada termasuk buku penunjang, dan kondisi pembelajaran yang sedang berjalan. Analisis siswa pada siswa kelas IV dan V SD di kota Malang yang menjadi subjek uji lapangan merupakan siswa dengan usia antara 10-11 tahun yang sebagian besar masih berada pada tahap operasional konkrit. Berdasarkan hal tersebut materi matematika yang mengandung kata-kata atau ide-ide abstrak akan mudah dipahami oleh siswa jika sebelumnya mereka diberikan contoh-contoh konkret dari lingkungan sekitarnya.

Analisis materi terkait kesulitan siswa dalam pelajaran matematika yaitu pada bangun datar dan bangun ruang. Siswa kelas IV dan V di SD kota Malang masih mengalami kesulitan dalam memahasi konsep keliling dan luas pada bangun datar serta luas dan volum pada bangun ruang. Untuk mengatasi hal itu maka diperlukan suatu langkah-langkah penanaman konsep yang membimbing siswa untuk menemukan sendiri konsep bangun datar dan bangun ruang dengan mengaitkan pada materi yang dipelajari sebelumnya. Berdasarkan hasil analisis awal, maka diperlukan suatu bahan ajar dalam bentuk modul yang dapat melatih pemahaman konsep matematika melalui pengalaman mandiri yang dikaitkan dengan kehidupan sehari-hari.

\section{Fase Prototipe}

Hasil perancangan pada fase prototipe ini berupa rancangan modul pembelajaran dengan pendeka$\tan$ CTL. Modul ini diberi terdiri dari lima bagian, 
yaitu (1) sifat-sifat bangun datar, (2) keliling dan luas bangun datar, (3) sifat-sifat bangun ruang, (4) Jaring-jaring bangun ruang, (5) luas dan volume bangun ruang. Berikut sintak modul pembelajaran geometri dengan pendekatan CTL. Komponen CTL, komponen modul, aktivitas siswa, dan contoh implementasi materi dalam modul pembelajaran Geometri, setiap tahapan sintaknya disajikan pada Tabel 1.

Berdasarkan sintak modul pembelajaran geometri dengan pendekatan CTL di atas, yang telah dimodifikasi terdiri dari 6 komponen yaitu (1) making meaningful connections, (2) self-regulated learning, (3) collaborating, (4) critical and creative thinking, (5) nurturing the individual, (6) reaching high standard and using authentic assessment. Modifikasi tersebut disesuaikan dengan komponen CTL yang dikembangkan oleh Johnson (2002: 24) dan Suryawati, Osman, \& Meerah (2010)

\section{Fase Asesmen}

Pada fase ini modul pembelajaran geometri dengan pendekatan CTL divalidasi oleh validator. Hasil validasi pada aspek kelayakan isi memperoleh tingkat kevalidan 3,5, aspek CTL memperoleh tingkat kevalidan 3,6, aspek sajian memperoleh tingkat kevalidan 3,67 dan aspek tampilan 3,87. Sehingga dari keseluruhan aspek memperoleh rata-rata sebesar 3,65 dengan kategori valid. Berdasarkan hasil validasi tersebut, maka modul pembelajaran geometri dengan pendekatan CTL dinyatakan valid dan dapat diterapkan di SD.

\section{PEMBAHASAN}

Hasil pengembangan produk modul belajar matematika menunjukkan bahwa modul sangat membantu dalam pembelajaran geometri di SD dan dapat melengkapi penggunaan bahan ajar di SD. Hal ini sesuai dengan fakta bahwa penggunaan bahan ajar pada pembelajaran di SD yaitu buku tematik yang disediakan oleh pemerintah seringkali terhambat pendistribusiannya sehingga menghambat proses pembelajaran (Yuniasih, 2013). Karakteristik bahan ajar matematika yang digunakan hanya berisi rangkuman materi, soal-soal rutin dan hanya ditekankan pada keterampilan berhitung, tidak ada umpan balik dan kurangnya penyajian konsep matematika. Dampak dari penggunaan bahan ajar tersebut, siswa kesulitan memahami materi serta ke- mampuan individu siswa kurang berkembang secara maksimal. Melalui modul yang telah dikembangkan, dapat diamati bawah siswa dapat lebih mudah dalam memahami materi dan mengembangan kemampuan individual siswa.

Hasil analisis siswa menunjukkan bahwa siswa kelas IV dan V SD di kota Malang yang menjadi subjek uji lapangan merupakan siswa dengan usia antara berada pada tahap operasional konkrit. Pada tahap ini siswa mulai mampu berfikir logik namun masih sebatas konkrit (Siegler, 2006). Sehingga dengan mengaitkan materi pelajaran dengan masalah nyata dalam kehidupan sehari-hari, siswa lebih memahami konsep matematika (Căprioară, 2015; Sukinah, 2016). Analisis materi terkait kesulitan siswa dalam pelajaran matematika yaitu pada bangun datar dan bangun ruang. Persamalahan geometri merupakan bidang yang paling terabaikan dalam kurikulum matematika di SD Kahfi (1997: 31) memang terbukti berdasarkan permasalahan siswa kelas IV dan V di SD kota Malang masih mengalami kesulitan dalam memahasi konsep keliling dan luas pada bangun datar serta luas dan volum pada bangun ruang. Untuk mengatasi hal itu maka diperlukan suatu langkah-langkah penanaman konsep yang membimbing siswa untuk menemukan sendiri konsep bangun datar dan bangun ruang dengan mengaitkan pada materi yang dipelajari sebelumnya.

Dari hasil analisis kesulitan siswa, diketahui bahwa dalam materi geometri siswa masih sering mengalami kesulitan sehingga perlu untuk dikembangkan. Persamalahan geometri ini merupakan bidang yang paling terabaikan dalam kurikulum matematika di SD. Sebagaimana menurut Kahfi (1997: 31) bahwa memang terbukti banyak siswa yang masih mengalami kesulitan dalam memahami operasi hitung pada bangun datar dan bangun ruang. Untuk mengatasi hal itu maka diperlukan suatu langkah-langkah penanaman konsep yang membimbing siswa untuk menemukan sendiri konsep bangun datar dan bangun ruang. Langkah-langkah tersebut kemudian diwujudkan dalam konsep CTL pada model yang dikembangkan secara bertahap.

Hasil uji validasi produk menunjukkan bahwa modul pembelajaran geometri yang dikembangkan dalam penelitian ini telah teruji valid dan dapat diterapkan di SD. Hasil ini didukung dengan modul pembelajaran geometri untuk siswa SD dengan kriteria valid sebelumnya telah dikembangkan 
Tabel 1. Tahapan Making Meaningful Connections

\begin{tabular}{|l|l|l|}
\hline \multicolumn{1}{|c|}{\begin{tabular}{c}
\multicolumn{1}{c|}{ CTL } \\
Components
\end{tabular}} & \multicolumn{1}{c|}{ Components of the Module } \\
\hline $\begin{array}{l}\text { Making meaningful } \\
\text { connections }\end{array}$ & $\begin{array}{l}\text { Contoh penggunaan atau penerapan } \\
\text { bangun datar dan bangun ruang dalam } \\
\text { kehidupan sehari-hari, seperti lapangan, } \\
\text { akuarium dll }\end{array}$ & $\begin{array}{l}\text { Mencermati contoh yang diberikan dan } \\
\text { menemukan contoh lain dari penggunaan atau } \\
\text { penerapan bangun datar dan bangun ruang } \\
\text { bilangan bulat dalam kehidupan sehari-hari }\end{array}$ \\
\hline
\end{tabular}

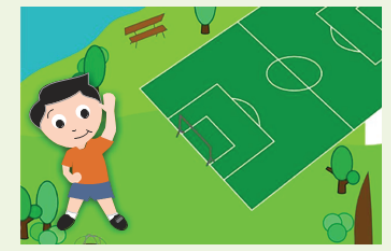

Dio sedang latihan lari.jarak jauh untuk mengikuti lomba 17 aqustusan. Dio latihan dilapangan belakang rumahnya. Ukuran lapangan adalah panjang $25 \mathrm{~m}$ dan lebar $13 \mathrm{~m}$. berapakah keliling lapangan yang dibuat latihan lari oleh dio?

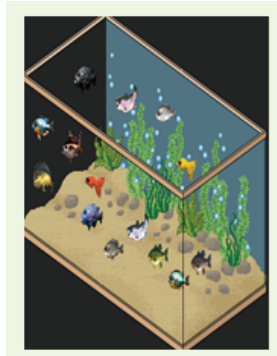

Ani adalah seorang siswa SD Sukamaju yang tengah duduk di kelas 4. Ani sangat suka dengan ikan sehingga dia memimpikan untuk memiliki akuarium sendiri di kamarnya. Dia menginginkan model akuarium seperti pada gambar di samping sehingga dia harus menyiapkan bahan-bahan yang diperlukan, salah satunya adalah kaca. Ukuran akuarium yang akan dibuatnya adalah panjang $50 \mathrm{~cm}$, lebar $30 \mathrm{~cm}$, dan tinggi $30 \mathrm{~cm}$. Dapatkah kalian membantu Ani untuk menghitung berapa luas kaca yang diperlukan untuk

Gambar 1. Example of implementation in the module

Tabel 2. Tahapan Self-regulated learning

\begin{tabular}{|c|l|l|}
\hline $\begin{array}{c}\text { CTL } \\
\text { Components }\end{array}$ & Components of the Module & \multicolumn{1}{c|}{ Students Activities } \\
\hline Self-regulated learning & Pemberian masalah & $\begin{array}{l}\text { Mengaitkan informasi yang diberikan untuk memben- } \\
\text { tuk soal kemudian menyelesaikannya }\end{array}$ \\
\hline
\end{tabular}

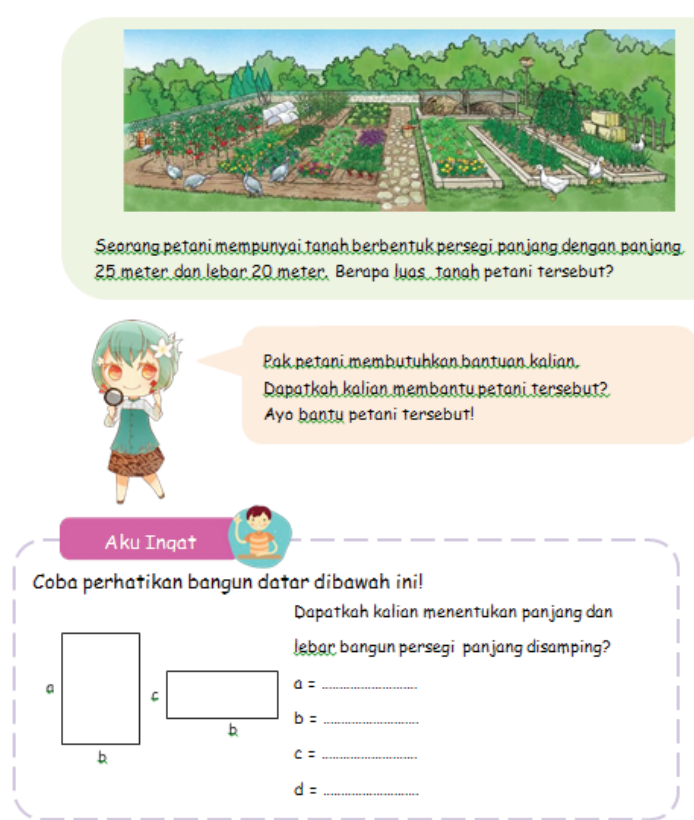

Gambar 2. Example of implementation in the module 
Tabel 3. Tahapan Collaborating

\begin{tabular}{|l|l|l|}
\hline $\begin{array}{c}\text { CTL } \\
\text { Components }\end{array}$ & Components of the Module & \multicolumn{1}{c|}{ Students Activities } \\
\hline Collaborating & Diskusi & $\begin{array}{l}\text { Berdiskusi dengan temannya terkait dengan soal open } \\
\text { endeed dan saling memeriksa jawaban }\end{array}$ \\
\hline
\end{tabular}

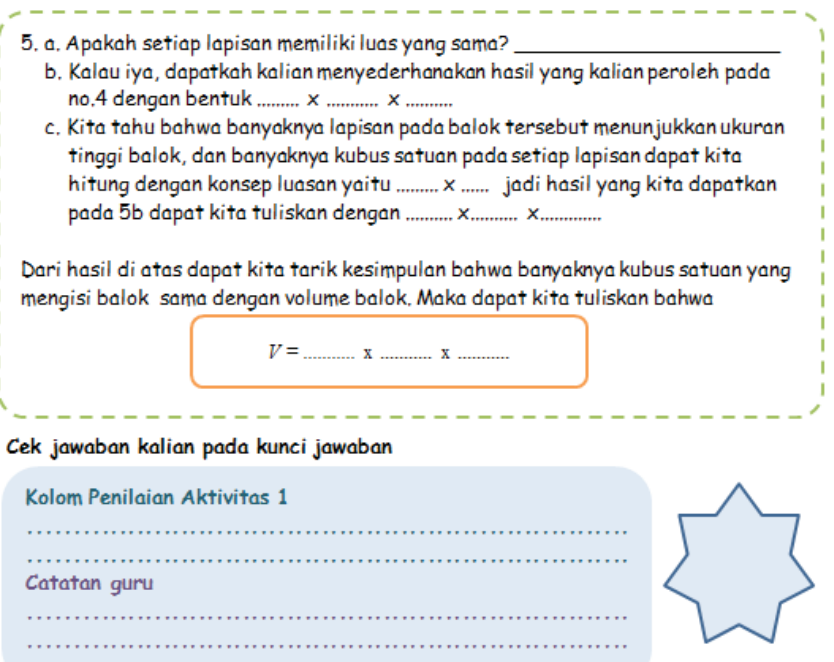

Gambar 3. Example of implementation in the module

Tabel. 4 Tahapan Critical and creative thinking

\begin{tabular}{|l|l|l|}
\hline \multicolumn{1}{|c|}{$\begin{array}{c}\text { CTL } \\
\text { Components }\end{array}$} & Components of the Module & \multicolumn{1}{c|}{ Students Activities } \\
\hline $\begin{array}{l}\text { Critical and cre- } \\
\text { ative thinking }\end{array}$ & $\begin{array}{l}\text { Pemberian masalah dalam } \\
\text { bentuk open-ended dan } \\
\text { Problem Solving }\end{array}$ & $\begin{array}{l}\text { Menyelesaikan masalah dengan beberapa cara dan memband- } \\
\text { ingkan jawabannya dengan jawaban temannya untuk kemudian } \\
\text { menarik kesimpulan dari jawaban-jawaban tersebut }\end{array}$ \\
\hline
\end{tabular}

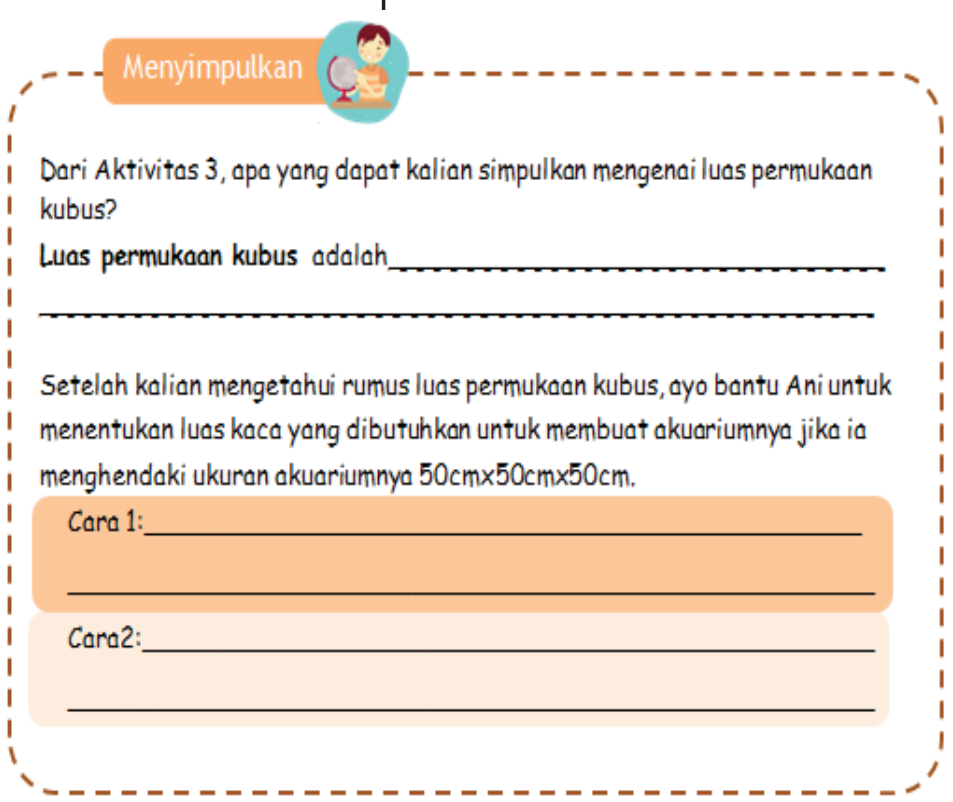

Gambar 4. Example of implementation in the module 
Tabel 5. Tahap Nurturing the individual

\begin{tabular}{|l|l|l|}
\hline \multicolumn{1}{|c|}{$\begin{array}{c}\text { CTL } \\
\text { Components }\end{array}$} & \multicolumn{1}{c|}{ Components of the Module } & \multicolumn{1}{c|}{ Students Activities } \\
\hline $\begin{array}{l}\text { Nurturing the } \\
\text { individual }\end{array}$ & $\begin{array}{l}\text { Pemberian cek kemampuan awal untuk } \\
\text { siswa serta bimbingan yang tertuang } \\
\text { dalam modul untuk dapat membuat kes- } \\
\text { impulan dari materi yang dipelajari }\end{array}$ & $\begin{array}{l}\text { Melakukan penilaian terhadap hasil belajarnya } \\
\text { dan kemudian mengikuti petunjuk yang ada untuk } \\
\text { melanjutkan belajarnya atau mengulangi serta bela- } \\
\text { jar untuk membuat kesimpulan }\end{array}$ \\
\hline
\end{tabular}

Berilah tanda $(\sqrt{ })$ pada kolom benar atau salah sesuai dengan yang kalia
pahami
\begin{tabular}{|c|l|l|l|}
\hline No. & \multicolumn{1}{|c|}{ Pertanyaan } & Benar & Salah \\
\hline 1. & $\begin{array}{l}\text { Keliling Sebuah bangun datar bisa } \\
\text { dihitung dengan cara menjumlahkan sis- } \\
\text { sisinya }\end{array}$ & & \\
\hline 2. & $\begin{array}{l}\text { Persegi panjang memiliki } 4 \text { pasang sisi } \\
\text { yang saling berhadapan }\end{array}$ & & \\
\hline 3. & Ada jenis segitiga sembarang & & \\
\hline 3. & $\begin{array}{l}\text { Luas bangun datar dapat dihitung } \\
\text { dengan cara persegi satuan. }\end{array}$ & & \\
\hline 4. & $\begin{array}{l}\text { Luas belah ketupat dan layang-layang } \\
\text { dapat dihitung dengan cara yang sama. }\end{array}$ & & \\
\hline 5. & $\begin{array}{l}\text { Untuk menghitung luas trapesium dan } \\
\text { jajar genjang dapat dihitung dengan } \\
\text { cara pendekatan Persegi panjang }\end{array}$ & & \\
\hline 6. & $\begin{array}{l}\text { Dalam mencari luas lingkaran } \pi=\frac{4}{7} \\
\text { a man }\end{array}$ & & \\
\hline
\end{tabular}

Setelah kalian menjawab semua pertanyaan di atas, cek jawaban kalian pada kunci jawaban halaman Keterangan:

- Jika semua jawaban kalian telah sesuai dengan kunci jawaban, maka kalian sudah memahami konsep dasar tentang bilangan bulat, sehingga kalian dapat langsung mempelajari subbab bilangan bulat pada garis bilangan

- Jika jawaban kalian masih ada yang belum sesuai dengan kunci jawaban, maka kalian harus mempelajari materi bilangan bulat ini mulai dariawal.

\section{Gambar 5. Example of implementation in the module}

Tabel 6. Tahap Reaching high standard and using authentic assessment

\begin{tabular}{|c|c|c|}
\hline $\begin{array}{c}C T L \\
\text { Components }\end{array}$ & $\begin{array}{c}\text { Components of the } \\
\text { Module }\end{array}$ & Students Activities \\
\hline $\begin{array}{l}\text { Reaching high } \\
\text { standard and using } \\
\text { authentic assessment }\end{array}$ & $\begin{array}{l}\text { Pemberian kolom pe- } \\
\text { nilaian secara mandiri } \\
\text { terhadap hasil belajar } \\
\text { siswa }\end{array}$ & $\begin{array}{l}\text { Menilai hasil belajarnya secara mandiri setelah menjawab uji } \\
\text { kompetensi yang diberikan serta memeriksa tugas-tugas yang } \\
\text { ada pada modul serta guru memberikan catatan-catatan terhadap } \\
\text { hasil pekerjaan siswa }\end{array}$ \\
\hline
\end{tabular}

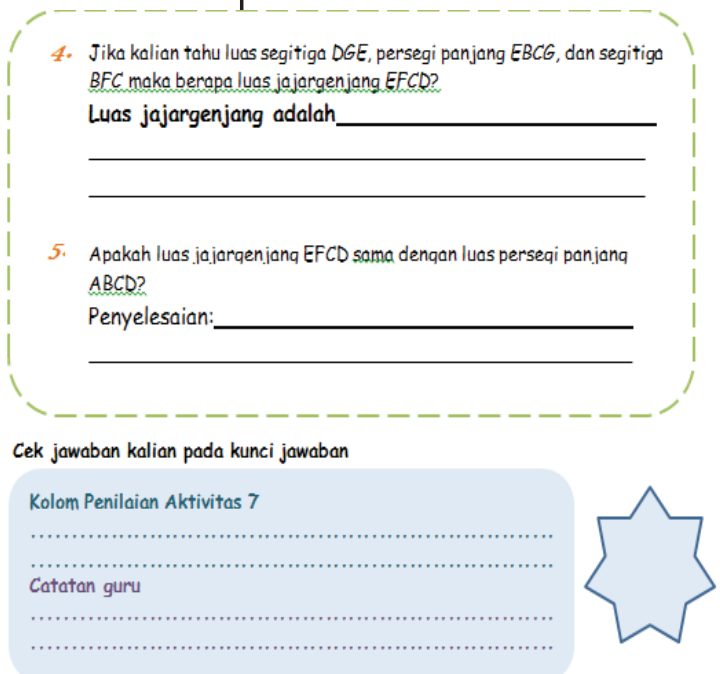

\section{Gambar 6. Example of implementation in the module}


dalam bentuk elektronik (Buchori \& Rahmawati, 2017). Selain itu modul geometri telah dapat meningkatkan pemahaman konsep dan minat siswa SMP (Lasmiyati, 2014) serta modul logika dapat hasil belajar siswa SMK (Windarti, 2015). Modul matematika dengan kriteria valid sebelumnya juga telah dikembangkan pada materi penjumlahan dan pengurangan bilangan bulat (Wahyuningtyas \& Shinta, 2017) pecahan (Suastika \& Tri Wahyuningtyas, 2018) serta lingkaran dan bola (Yunita, 2016).

Pengembangan potensi siswa melalui model di atas juga sesuai dengan orientasi kurikulum 2013 yang meningkatkan dan menyeimbangkan antara kompetensi sikap (attitude), keterampilan (skill), dan pengetahuan (knowladge). Kurikulum 2013 untuk SD/MI dikembangkan dengan menggunakan pendekatan tematik terpadu dari kelas I sampai kelas VI yang pelaksanaannya dilakukan secara bertahap. Pelaksanaan Kurikulum 2013 untuk SD/MI dikembangkan dengan menggunakan pendekatan tematik terpadu yang memungkinkan siswa, baik secara individu maupun kelompok, aktif menggali dan menemukan konsep serta prinsipprinsip keilmuan secara holistik, bermakna, dan otentik (Majid, 2014:80). Pembelajaran terpadu berawal dari masalah yang sesuai dengan kondisi (contextual problem) yang kemudian dikembangkan dengan pengetahuan yang sudah dimiliki oleh siswa untuk konstruksi pengetahuannya.

Bahan ajar dalam bentuk modul hendaknya dapat digunakan secara mandiri, dimana setiap siswa dapat belajar sesuai dengan kecepatan masing-masing secara efektif. Model tersebut dikembangkan tidak tergantung pada media lain dengan karakteristik materi pada modul dikembangkan secara up to date dan kontekstual (Irawan, 2013). Pembelajaran dengan modul telah memberikan kontribusi yang signifikan terhadap peningkatan dan perolehan hasil belajar untuk siswa sekolah dasar melalui model yang telah memenuhi kriteria valid, praktis, dan efektif (Wahyuningtyas \& Shinta, 2017). Dari hasil wawancara terbatas terhadap beberapa guru dan siswa mengenai penggunaan modul dengan pendekatan CTL, dapat disimpulkan bahwa modul dapat membantu guru dalam memperdalam materi yang belum ada di buku teks dan siswa sangat antusias karena kegiatan dalam modul dapat membantu siswa dalam memahami materi.

\section{SIMPULAN DAN SARAN}

Hasil investigasi awal penelitian menunjukkan bahwa penggunaan bahan ajar dalam penyajian konsep matematika masih kurang optimal sehingga siswa kesulitan memahami materi terutama pada materi geometri yaitu bangun datar dan bangun ruang. Kemampuan mandiri individu siswa kurang berkembang secara maksimal dengan pemberian soal rutin. Berdasarkan permasalahan tersebut telah dikembangkan modul pembelajaran geometri dengan pendekatan CTL pada penelitian ini. Modul pembelajaran geometri dengan pendekatan CTL dikembangkan dengan 6 komponen yaitu (1) making meaningful connections, (2) self-regulated learning, (3) collaborating, (4) critical and creative thinking, (5) nurturing the individual, (6) reaching high standard and using authentic assessment. Hasil validasi pada aspek kelayakan isi, CTL, sajian, dan tampilan memperoleh rata-rata sebesar 3,65 dengan kategori valid. Berdasarkan hasil validasi tersebut, maka modul pembelajaran geometri dengan pendekatan CTL dinyatakan valid dan dapat diterapkan di SD. Dari hasil penelitian ditemukan bahwa terdapat beberapa bagian isi maupun penyajian modul yang masih perlu dikembangkan pada pembelajaran untuk siswa SD sehingga disarankan untuk mengembangkan modul dengan materi lain serta dengan pendekatan pembelajaran yang berbeda. Ucapan terimakasih disampaikan kepada Kemenristek DIKTI yang telah membiayai penelitian ini.

\section{DAFTAR RUJUKAN}

BSNP. 2006. Standar Kompetensi dan Kompetensi Dasar Matematika. Jakarta: Departemen Pendidikan Nasional.

Buchori, A., \& Rahmawati, N. D. (2017). Pengembangan E-Modul Geometri dengan

Pendekatan Matematika Realistik di Sekolah Dasar. Jurnal Sekolah Dasar, 2(1), 23-29.

Căprioară, D. (2015). Problem Solving - Purpose and Means of Learning Mathematics in School. Procedia - Social and Behavioral Sciences, 191, 1859-1864.

Depdiknas. 2006. Peraturan Menteri Pendidikan Nasional Republik Indonesia (Permendiknas) Nomor 22 Tahun 2006 Tentang Standar Isi Sekolah. Jakarta: Depdiknas. 
Johnson, Elaine B. 2002. Contextual Teaching and Learning: What it is and why it's here to stay. California: A Sage Publications Company.

Johnson, Elaine B. 2002.Contextual Teaching and Learning: Menjadikan Kegiatan BelajarMengajar Mengasyikkan dan Bermakna. Terjemahan oleh Ibnu Setiawan. 2009. Bandung: MLC.

Kahfi, M. S. 1997. Membenahi Pembelajaran Geometri di Sekolah Melalui Teori Van Hiele. Journal For Math, III(2), 31.

Lasmiyati, I. H. (2014). Pengembangan Modul Pembelajaran untuk Meningkatkan Pemahaman Konsep dan Minat SMP Developing a Module to Improve Concept Understanding and Interest of Students of SMP. Pythagoras: Pendidikan Matematika, 9(2), 161-174.

Majid, Abdul. 2014. Pembelajaran Tematik Terpadu. Bandung: PT Remaja Rosdakarya.

Nurhadi., \& Senduk, Agus G. 2009. Pembelajaran Kontekstual. Surabaya: PT JePe Press Media Utama.

Plomp, T. 2007. Formative Evaluation in Educational Design Research: An Introduction to Educational Design Research. Makalah disajikan pada Proceedings of the Seminar Conducted At The East China Normal University, Shanghai (PR China), November $23-26$.

Siegler, R.S. 2006. How Children Development. New York: Word Publishers.

Suastika, I. K., \& Tri Wahyuningtyas, D. (2018). Developing Module of Fractional Numbers using Contextual Teaching and Learning Approach. Pancaran Pendidikan, 7(1), 23-32.
Sukinah. (2016). Penerapan Model Pembelajaran Contextual Teaching And Learning Sebagai Upaya Untuk Meningkatkan Prestasi Matematika Materi Peluang. Jurnal Pendidikan, 1(2), 190-204.

Suryawati, E., Osman, K., \& Meerah, T. S. M. (2010). The Effectiveness of RANGKA Contextual Teaching and Learning on Student's Problem Solving Skills and Scientific Attitude. Procedia - Social and Behavioral Sciences, 9, 1717-1721.

Trianto. 2010. Model Pembelajaran Terpadu. Jakarta: PT Bumi Aksara.

Wahyuningtyas, D. T., \& Shinta, R. N. (2017). Developing Addition And Subtraction Of Integers Learning Module Using CTL ( Contextual Teaching And Learning ) Approach Based On Curriculum 2013. Pancaran Pendidikan, 6(3), 177-182.

Windarti. (2015). Pengembangan Modul Pembelajaran Logika yang Memuat Pendidikan Karakter untuk Siswa Kelas X SMK Developing a Logic Learning Module Loaded with Character Education for Class X Students of SMK. Phytagoras: Jurnal Pendidikan Matematika, 10(1), 106-116.

Yuniasih, N. (2013). Analisis Pendekatan Saintifik Pada Kurikulum 2013 Di SDN Tanjungrejo 1 Malang. Jurnal Inspirasi Pendidikan Universitas Kanjuruhan Malang, 2(1) 574-581.

Yunita, A. (2016). Development A Constructivist Module And Web On. Journal on Mathematic Education, 7(2), 109-116. 